\title{
Geological report to the Ahtna Corporation, Copper River basin, Alaska, 1975
}

Powell, Doug, and Amoco Oil Co.

GMC DATA REPORT 455

This GMC data report from the Amoco Heritage collection has been made available through funding from the FY2018 USGS National Geological and Geophysical Data Preservation Program, Grant Number G18AP00054. This project report is presented in its original format and has not been reviewed for technical content or for conformity to the editorial standards of DGGS. It should not be used or cited as reviewed data.

2019

State of Alaska

Department of Natural Resources

Division of Geological \& Geophysical Surveys

GEOLOGIC MATERIALS CENTER
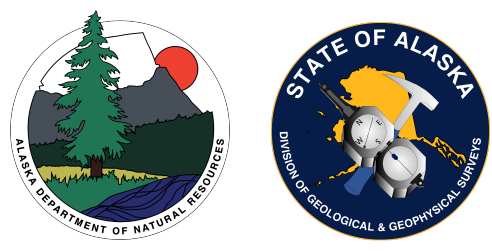
Amoco Production Company COPPER RIVER BASIN, ALASKA

\section{GEOLOGICAL REPORT TO}

THE AHTNA CORPORATION

CF 750040 november, 1975

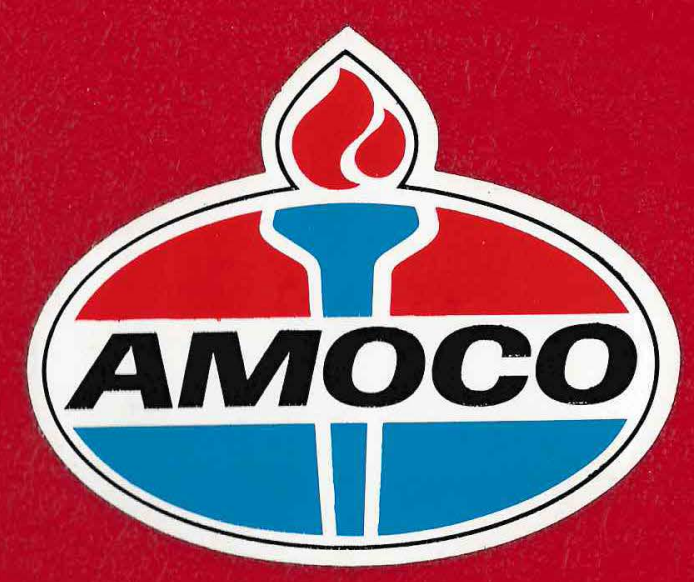


GEOLOGIC REPORT

COPPER RIVER BASIN

ALASKA

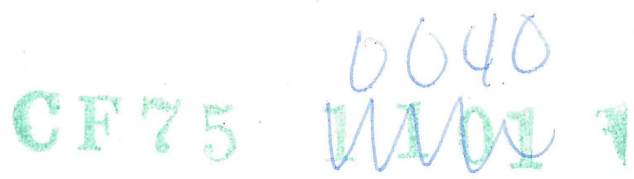

by

Doug Powell

Amoco Production Company

November, 1975 
TABLE OF CONTENTS

$\underline{\text { Page }}$

INTRODUCTION

1

General Discussion 1

Purpose 2

Methods of Investigation 2

Conclusions 3

STRATIGRAPHY 4

Regional Geology 4

Western Copper River Basin 5

Ahtna Corporation Contract Area 6

Lower Cretaceous 6

Nelchina Formation 6

Environment of Deposition 7

Upper Cretaceous 8

Matanuska Formation 8

$\begin{array}{ll}\text { STRUCTURE } & 10\end{array}$

Regional 10

West Copper River Basin 10

East Copper River Basin 10

Central Copper River Basin 11

South Copper River Basin 11

$\begin{array}{ll}\text { Summary } & 12\end{array}$

$\begin{array}{ll}\text { REFERENCES } & 14\end{array}$

APPENDIX

Paleontology

Core Data.

List of Measured Sections

Field Notes

Explanation of Plotted Sections

Plotted Sections

In Pocket

FIGURES
Figure 1
Figure 2
Index Map
Composite Stratigraphic Section west side of Copper River Basin
Figure 3
Geologic Column for Eastern Copper River Basin

ENCLOSURES

1. Geologic Map

In Pocket

2. Structural Cross-Sections

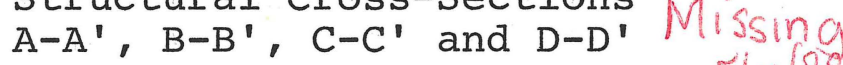

In Pocket 
ENCLOSURES (continued)

3. Nelchina Formation: Gross sand and In Pocket

Trend Map

4. Stratigraphic Cross-Section E-E'

5. Stratigraphic Cross-Section F-F'

6. Stratigraphic Cross-Section G-G'

In Pocket

In Pocket

In Pocket 


\title{
AMOCO PRODUCTION COMPANY \\ COPPER RIVER BASIN, ALASKA
}

\author{
GEOLOGICAL REPORT TO THE AHTNA CORPORATION \\ Denver Division Geological \\ Report No. 154 \\ South-Central Alaska \\ Project No. 74-26 \\ November, 1975
}

\section{INTRODUCTION}

GENERAL DISCUSSION:

The Copper River Basin is an intermontane basin located in south-central Alaska (Fig. 1, Encl. 1). The basin is encircled by mountain ranges: the Alaska Range and its low foothills to the north, the Wrangell Mountains to the east, the Chugach Mountains to the south, and on the west by the Talkeetna Mountains.

Within the broadly defined region a much more restricted area is considered suitable for hydrocarbon exploration (outlined by red tape on Encl. 1). This area contains about 92 townships $(2,119,680$ acres $)$ and averages about 42 miles wide, north to south; and about 82 miles in length. Black tape on Enclosure 1 encloses the Ahtna Corporation contract area which covers the approximate eastern half of the prospective basin area. The flat to rolling nature of the terrain within the contract area (west of the Copper River Valley) is shown by photos 1, 2, and 3 . 


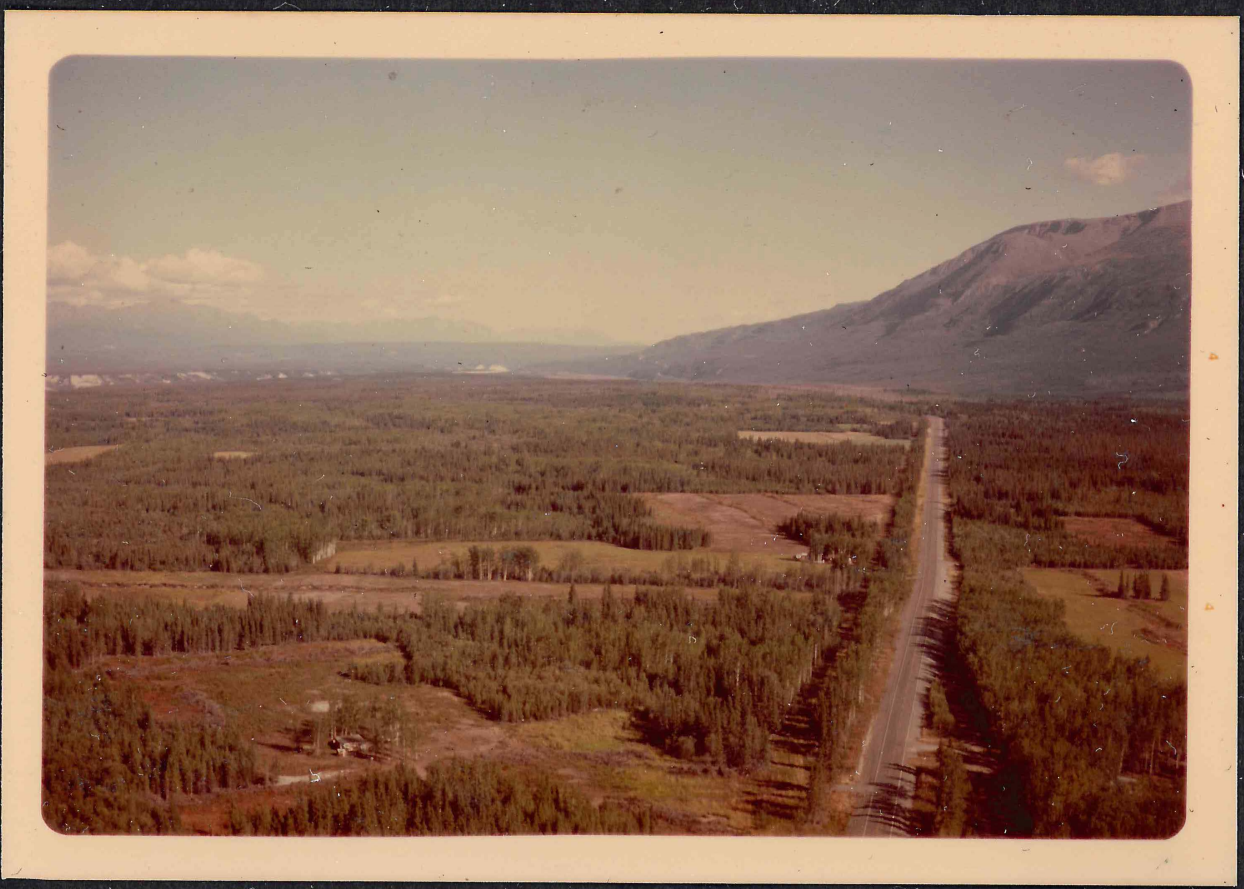

Photo 3: Looking southeast along Copper River - Edgerton Highway toward Lower Tonsina. 


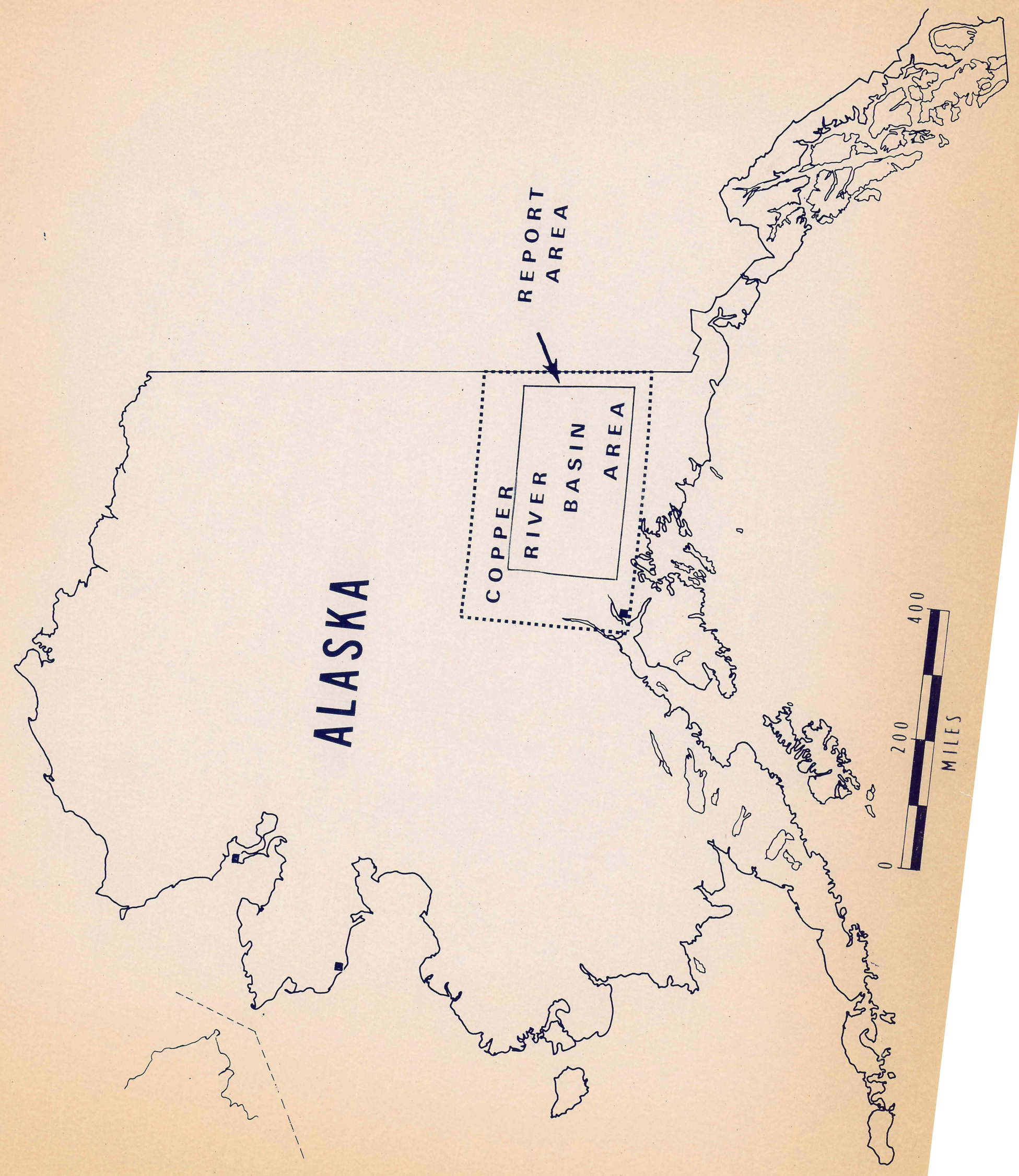




\section{PURPOSE:}

The purpose of this report is to present the geology of the Copper River Basin area (Fig. 1, Encl. 1) of southcentral Alaska and provide a stratigraphic interpretation of the prospective Ahtna Corporation contract area (Encl. 1) on which seismic program has been shot and current program is now in progress.

This study was conducted under Project No. 74-26 to evaluate the hydrocarbon possibilities of the area with primary emphasis on the stratigraphy of the Jurassic and Lower Cretaceous rock units.

\section{METHODS OF INVESTIGATION:}

A regional surface geology map (Encl. 1) was compiled primarily from U. S. Geological Survey data (see Reference list) to delineate the distribution of rock units within and around the Copper River Basin and to determine the outcrops available and accessible for field work.

During the summer of 1974, a two-month field program was undertaken in the Copper River Basin Area to study the stratigraphy of the prospective horizons. The data have been evaluated, with limited subsurface well data incorporated into the interpretation. Measured sections and field notes are included as an appendix to this report. Reconnaisance geophysical program during the 1974-1975 shooting season (lines shown by green tape on Encl. 1) discovered anomalies 
within the Ahtna Corporation contract area that merited additional reconnaissance and detail seismic program for the 1975-1976 field season.

\section{CONCLUSIONS :}

The Ahtna contract area of the eastern Copper River Basin is prospective for oil and gas exploration of the Lower Cretaceous-Nelchina Formation because of the following qualities :

1. Favorable Nelchina Formation sand trends exist as shown on Enclosure 3.

2. Favorable reservoir qualities are present in the Nelchina sandstones.

(a) Outcrop samples on west and east side of the basin exhibit porosity and permeability and have strong oil odor. Possible oil stain was found on the west side at Limestone Gulch (Encl. 4).

(b) The Pan American No. I Moose Creek and Mobil No. I Salmon Berry Lake blew out and flowed appreciable amounts of water with slight gas shows.

3. Numerous seismic structural leads have been mapped in the contract area.

4. Basinal shales of the Middle and Upper Jurassic and the Lower and Upper Cretaceous should provide adequate source beds for hydrocarbons in the copper River Basin. 


\section{STRATIGRAPHY}

REGIONAL GEOLOGY

During the late Paleozoic Era, southern Alaska was a region of eugeosynclinal deposition (now being referred to as Volcanic Island Arc). A thick sequence of volcanic and volcaniclastic rocks was deposited during the Pennsylvanian Period (Richter and Jones, 1973), overlain by Permian limestones, shales, siltstones and sandstones. This sequence is overlain by subaerial basaltic lava flows, limestones, shales and cherts of Upper Triassic age, followed by volcanic and volcaniclastic rocks of the Lower Jurassic-Talkeetna Formation in the Talkeetna and northern Chugach Mountains. At the same time, shales, limestones, spiculites, cherts and argillites of the McCarthy and Lubbe Creek Formations were deposited in the Wrangell Mountains (Imlay and Detterman, 1973)

Near the end of the Lower Jurassic period the rocks of the eugeosyncline were deformed, intruded by the granitic "Kosina Batholith" in the Talkeetna Mountains (Grantz, et al, 1963) and metamorphosed by a period of orogeny which formed the Matanuska geosyncline (Payne, 1955), in which the prospective rocks of the Copper River Basin were deposited.

In the western part of the Copper River Basin over 17,000' of marine sediments were deposited in the Matanuska Geosyncline from Middle Jurasic to Upper Cretaceous time (Shaw, 1960). The source of these sediments was the emergent 
area to the west and north in the Talkeetna Mountains and possibly around the northern part of the basin, with most of the clastics derived from early Mesozoic volcanics. After the quartz diorite batholith of the Talkeetna Mountains was unroofed in middle Upper Jurassic time, the sediments were dominantly quartz with a high feldspar content (Shaw, 1960).

Uplift and erosion followed the deposition of the Tuxedni Formation, but folding was apparently not pronounced, as the Chinitna Formation lies on the Tuxedni Formation with no angular discordance. The Upper Jurassic-Naknek Formation unconformably overlies the Chinitna Formation.

Uplift and folding occurred at the end of the Jurassic followed by deposition of sandstones, limestones, siltstones and shales of the Lower and Upper Cretaceous rocks.

At the end of Upper Cretaceous time, uplift and erosion occurred, followed by deposition of Continental fluviatile deposits of conglomerate, sandstone, shale and coal.

In Late Tertiary time, the region was again deformed and the basin edges uplifted. Quaternary deposits have concealed most of the Tertiary and Upper Cretaceous deposits in the Copper River Basin.

WESTERN COPPER RIVER BASIN

On the west side of the basin, the composite stratigraphic section attains a thickness of about 20,000' of Middle 
Jurassic through Tertiary sediments (Fig. 2). Due to truncation and non-deposition, the thickness of the geologic column ranges considerably around the basin margins so that an average figure of about $10,000^{\prime}$ is anticipated for the deeper portions of the basins.

\section{AHTNA CORPORATION CONTRACT AREA}

The geologic column for this area is shown by the Pan American \#1 Moose Creek Unit (Fig. 3). Only 7020' of Lower Cretaceous to Tertiary are present above the Lower Jurassic(?)Talkeetna Formation. The Middle Jurassic-Tuxedni sandstones, and Upper Jurassic-Chinitna and Naknek sandstones which are prospective on the west side of the basin have been removed by pre-Lower Cretaceous erosion. Information concerning the Jurassic sands was submitted in the first report to the Ahtna Corporation (Amoco, 1974). The Nelchina Formation in the Moose Creek well is 1083' thick, containing upper and lower sand zones totaling 480-550' sandstone. The well blew out at 6074' while drilling and flowed some gas and water at the rate of $848 \mathrm{BWPD}$. $20,252 \mathrm{BWP}$

The primary objective horizon in the Eastern Copper River Basin is the Nelchina Formation. See Enclosure 3 for trends of the gross sand isopach across the Ahtna Corporation contract area.

\section{LOWER CRETACEOUS}

NELCHINA FORMATION (Neocomian Age)

The Nelchina Formation crops out the west and east sides 
of the basin (Encls. $1 \& 3$ ) and is present in the subsurface at the Pan American \#I Moose Creek Unit and the Mobil \#I Salmon Berry Lake Unit. It ranges in thickness from 70' to 1900'. At Limestone Gulch (Encl. 4), the Nelchina is 1238 thick consisting of three Units, a lower sandstone 520' thick overlain by $120^{\prime}$ of bioclastic limestone (Calcarenite composed mostly from pulverized Inoceramus shells), and an upper sandstone 495' thick. The sandstones are arkosic, and poorly cemented to friable. Measured porosities from the better cemented samples vary from $14.8 \%$ to $24.3 \%$, with permeabilities from .34 to $669 \mathrm{mds}$. The upper $700^{\prime}$ of the Upper, Middle and Lower Nelchina have a strong petroleum odor, and possible olive-brown oil stain. These sands were derived predominantly from a quartz diorite batholith to the west and north which became a source for sediments about the middle of the Upper Jurassic (Shaw, 1960). For additional details see Geologic Report by Amoco (1974).

\section{ENVIRONMENT OF DEPOSITION:}

The Nelchina Formation is a shelf deposit, more specifically nearshore shoals and bar deposits which onlap the eroded surface of the Upper Jurassic-Naknek Formation (Encl. $3 \& 4$ ).

At Bubb Creek (Limestone Gap) section (Encl. 4), a subaqueous distributary system is evidently the conduit which brings much of the clastics into the system. The pulverized Inoceramus shells, of which the limestone is composed, 
and the wave ripples attest to the strong wave action.

Cross Sections F-F' and G-G' (Encls. $5 \& 6$ ) provide the control data for the sand isopach and trends (Encl. 3) of the Nelchina Formation in the southwest Wrangell and north Chugach Mountains. Several evidences for subaqueous distributary systems are present.

The Chetaslina River and Cheshnina River sections (Nos. $40 \& 41$ respectively, in pocket), originally considered of Upper Jurassic Age (Grantz, 1966), are now new points of control for the Lower Cretaceous-Nelchina Formation. Approximately 1000' \pm calcareous sandstone is present at the Cheshnina River Section. Core analysis of a sample at bottom of the section shows $9.9 \%$ porosity and permeability of 55.8 mds. Sandstones are grey to brownish grey with scattered pebble conglomeratic lenses, carbonates, and are fine to coarse grained. A few plant (fern) fossils, carbonized wood and part of an Ammonite was found. Only 520' of sandstone was measured on the Chetaslina River. About 120' of silty limestone to limy siltstone with ?Inoceramus prisms and possible abundant crushed pelecypod shells overlie the sandstones. Both sections are dipping about $25^{\circ} \mathrm{SW}$, basinward.

\section{UPPER CRETACEOUS}

MATANUSKA FORMATION

A secondary objective horizon in the Ahtna contract area is the Upper Cretaceous - Matanuska Formation. The sand zones 
encountered at the Pan American \#I Moose Creek Well between 3783-4759' are not clean in the Moose Creek area, but may be more prospective northward toward its source area (see Amoco, 1974, for more detailed information.) 


\section{STRUCTURE}

REGIONAL

The Copper River Basin is a large structural and topographic basin covered by Quaternary glacio-alluvial deposits and surrounded by mountain ranges composed of folded Paleozoic and early Mesozoic sedimentary and igneous rocks. It was formed by a major orogeny in Early Jurassic time as a depression in the folded and metamorphosed contents of an older eugeosyncline.

WEST COPPER RIVER BASIN

Structures of the Nelchina area, such as the Sheep and Horn Mountains are large anticlinal features that plunge northeastward. Structural cross-section A-A' (Encl. 2) shows the NW-SE interpretation from the Talkeetna Mountains across the Nelchina area on to the Chugach Mountains (Grantz, 1965).

The Castle Mountain and Caribou Faults are two rightlateral strike-slip fault systems which trend easterly across the Nelchina area and divide it into three blocks (Grantz, 1965). These two faults merge in the Central Matanuska Valley and form the north bounding fault of the lower Matanuska Valley.

\section{EAST COPPER RIVER BASIN}

Structures of the southwest Wrangells trend northwestward parallel to the strike of the beds with much high angle 
reverse faulting, see structural sections $B-B^{\prime}$ and $C-C^{\prime}$

(Encl. 2). Southwest basinward dips of $20^{\circ}-25^{\circ}$ SW were noted at the Lower Cretaceous-Snider Peak, Chetaslina and Cheshnina River Sections.

The structural grain of the McCarthy area - Upper Chitina Valley is also northwestward. The structural interpretation of the eastern Wrangells is shown by Section D-D' (Encl. 2).

\section{CENTRAL COPPER RIVER BASIN}

Seismic program indicates an east-west alignment of the structures in the Ahtna Corporation contract area as does the alignment of the Permo-Pennsylvanian meta-volcanics and the Triassic-Nikolai Greenstone along the north flank of the basin.

SOUTH COPPER RIVER BASIN

Along most of the north flank of the Chugach Mountains, southern Wrangells, and along the entire Chinitna Valley there is evidence to support a major uplift and folding in Late Jurassic time followed by southward truncation of the geologic column down to the Permo-Pennyslvanian meta-volcanics and meta-sediments. Subsequently, the Wrangell positive was formed in latest Jurassic time. The Lower Cretaceous sea transgressed northward depositing the Nelchina Formation, progressively onlapping the highly disected older formations. In turn, the Albian Age-Kennicott Formation onlapped the Nelchina Formation. This continued into the Upper Cretaceous 
with numerous oscillations of the sea recorded by the geologic section. In Late Campanian-Maestrichtian time, the MacColl Ridge Formation represents a regressive series caused by the rejuvenation of the Wrangell Positive. There is no record of the early Tertiary periods. In Miocene time, the continental fluviatile sediments of the Frederika Formation, up to 2000' thick, were deposited and in places intercalated with flows of Wrangell lavas. Igneous intrusives were common.

The Wrangell lava superceded the Frederika Formation, building the gigantic Wrangell pile from Miocene time to Recent. A period of regional folding and faulting apparently took place in Late Tertiary time.

\section{SUMMARY :}

The Matanuska geosyncline was formed in Early Jurassic time. Throughout Middle and Upper Jurassic time, nearshore and rather shallow basin sediments were deposited along an unstable shelf as evidenced by unconformities within the column. In Late Jurassic time, major uplift and folding occurred along the southern Wrangells, Chitina Valley and Chugach Mountains at least along the eastern portion of the southern flank of the Copper River Basin. The sedimentary column down to the Early Paleozoics were stripped along the southern Wrangell and Chugach Mountains. Subsequently, the Wrangell positive developed as well as the emergent Talkeetna High. The Lower Cretaceous seas transgressed northward depositing nearshore sediments of Neocomian and Albian age 
on the unstable shelf. This continued into the Upper cretaceous with numerous oscillations of the sea, whe more basinal Matanuska Formation and coeval rock were deposited. Regression and uplift with folding occurred at the end of Cretaceous time. This resulted in a depositional and structural belt which essentially parallels the present arcuate coast line. 


\section{REFERENCES}

Cited and used in compilation of the geologic map

(Encl. No. 1).

Amoco Production Co., 1974, Geological Report: Copper River Basin, sent to Ahtna Corporation October 28, 1974.

Armstrong, A. K., Mackevett, E. M., Jr., and Silberling, N. J., 1970, The Chististone and Nizina Limestones of part of the southern Wrangell Mountains, Alaska - a preliminary report stressing carbonate petrography and depositional environment in Geol. Survey Research 1969: U.S. Geol. Survey Prof. Paper. 650-D, p. D49-D62.

Barnes, F. F., 1962, Geologic map of lower Matanuska Valley, Alaska: U.S. Geol. Survey Misc. Geol. Inv. Map I-359, scale $1: 63,360$.

Beikman, H. M., 1974, Preliminary Geologic Map of the Southeast Quadrant of Alaska, U. S. Geol. Survey, Miscellaneous Field Studies, MF-612, 2 sheets.

Bishop, R. E., 1965, Cretaceous geology of the western Copper River basin: Amoco Production Co., Anchorage District Geol. Report No. 11A-11, 5p.

Berg, H. C., Jones, D. L., and Richter, D. H., 1972, GravinaNutzotin belt - tectonic significance of an Upper Mesozoic sedimentary and volcanic sequence in southern and southeastern Alaska: U.S. Geol. Survey Prof. Paper 800-D, p. D1-D24.

Capps, S. R., 1927, Geology of the upper Matanuska Valley, Alaska, with a section on the igneous rocks by J. B. Mertie, Jr.: U. S. Geol. Survey Bull. 791, 92pp.

1940, Geology of the Alaska Railroad region: U.S. Geol. Survey Bull. 907,201 pp.

Chapin, Theodore, 1918, The Nelchina-Susitna region, Alaska: U.S. Geol. Survey Bull. 668, $67 \mathrm{pp}$.

Clark, S. H. B., 1972, Reconnaissance bedrock geologic map of the Chugach Mountains near Anchorage, Alaska: U.S. Geol. Survey Misc. Field Studies Map MF-350.

- 1973, The McHugh Complex of south-central Alaska: U.S.Geol. Survey Bull. 1372-D, p. Dl-Dll.

Detterman, R. L., Reed, B. L., and Lanphere, M. A., 1965, Jurassic plutonism in the Cook Inlet region, Alaska: U.S. Geol. Survey Prof. Paper 525-D, p. D16-D21. 
Foster, H. L., 1970, Reconaissance geologic map of the Tanacross Quadrangle, Alaska: U.S. Geol. Survey Misc. Geol. Investigations Map I-593.

Geological and Geophysical Programs, 1973, Regional Geology of the Susitna-MacLaren River Area: Annual Report, U.S. Geol. Survey.

Grantz, Arthur, 1953, Preliminary report on the geology of the Nelchina area, Alaska: U.S. Geol. Survey open-file report, 3 maps, 1 explanation, 9 figs. May 27, 1953.

- 1960a, Generalized geologic map of the Nelchina area, Alaska, showing igneous rocks and larger faults: U.S.Geol. Survey Misc. Geol. Inv. Map I-312.

- 1960b, Geologic map of Talkeetna Mountains (A-2) quadrangle, Alaska, and the contiguous area to the north and northwest: U.S. Geol. Survey Misc. Geol. Inv. Map I-313.

, 1960c, Geologic map of Talkeetna Mountains (A-1) quadrangle and the south third of Talkeetna Mountains (B-I) quadrangle, Alaska: U.S. Geol. Survey Misc. Geol. Inv. Map I-314.

196la, Geologic map and cross sections of the Anchorage (D-2) quadrangle and northeasternmost part of the Anchorage (D-3) quadrangle, Alaska: U.S. Geol. Survey Misc. Geol. Inv. Map I-342.

- 1961b, Geologic map of the north two-thirds of the Anchorage (D-1) quadrangle, Alaska: U.S. Geol. Survey Misc. Geol. Inv. Map I-343.

' 1964, Stratigraphic reconnaissance of the Matanuska Formation in the Matanuska Valley, Alaska: U.S. Geol. Survey Bull. 1181-1, 33p., 3 figs.

- 1965, Geologic map and cross sections of the Nelchina area, south-central Alaska: U.S. Geol. Survey open-file map, July 2, 1965, 4 sheets, scale 1:63,360.

, 1966, Strike-slip faults in Alaska: U.S. Geol. Survey open-file report, 82 p., 8 figs.

Grantz, Arthur, and Jones, D. L., 1960, Stratigraphy and age of the Matanuska Formation, south-central Alaska, in Short papers in the geological sciences: U.S. Geol. Survey Prof. Paper 400-B, p. B347-B350.

Grantz, Arthur, White, D. E., Whitehead, H. C., and Tagg, A. R., 1962, Saline Springs, Copper River Lowland, Alaska: Am. Assoc. Petroleum Geologists Bull., v. 46, no. 11, p. 11902002 . 
Grantz, Arthur, Thomas, Herman, Stern, T. W., and Sheffey, N. B., 1963, Potassium-argon and lead-alpha ages for stratigraphically bracketed plutonic rocks in the Talkeetna Mountains, Alaska: U.S. Geol. Survey Prof. Paper 475-B, p. B56-B59.

Grantz, Arthur, Jones, D. L., and Lanphere, M. A., 1966 , Stratigraphy, paleontology, and isotopic ages of upper Mesozoic rocks in the southwestern Wrangell Mountains, Alaska: U.S. Geol. Survey Prof. Paper 550-C, p. C39C47.

Imlay, R. W. and Detterman, R. L., 1973, Jurassic paleobiogeography of Alaska, U.S. Geol. Survey Prof. Paper 801.

Jones, D. L., 1964 [1963], Upper Cretaceous (Campanian and Maestrichtian) ammonites from southern Alaska: U.S. Geol. Survey Prof. Paper 432, 53p., 45 pls., 25 figs., 2 tables.

, 1973, The Boreal Lower Cretaceous, Proceedings of an International Symposium: Geol. Journal Special Issue No. 5, December.

Jones, D. L., and Berg, H. C., 1964, Cretaceous stratigraphy of the McCarthy A-4 quadrangle, southern Alaska: U.S. Geol. Survey Bull. 1180-A, 18p., 1 pl., 6 figs.

Jones, D. L., and Clark, S. H. B., 1973, Upper Cretaceous (Maestrichtian) fossils from the Kenai-Chugach Mountains, Kodiak and Shumagin Islands, southern Alaska: U.S. Geol. Survey Jour. Research, v. 1, no. 2, p. 125-136.

Jones, D. L., and Mackevett, E. M., Jr., 1969, Summary of Cretaceous stratigraphy in part of the McCarthy quadrangle, Alaska: U.S. Geol. Survey Bull. 1274-K, p. Kl-K19.

Jones, D. L., Mackevett, E. M., Jr., and Plafker, George, 1971, Speculations on Late Mesozoic tectonic history of part of southern Alaska [abs.]: Internat. Symposium Arctic Geology 2d, San Francisco, Calif., 1971, p. 30.

Mackevett, E. M., Jr., 1963, Preliminary geologic map of the McCarthy C-5 quadrangle, Alaska. U.S. Geol. Survey Misc. Geol. Inv. Map I-406.

1965a, Preliminary geologic map of the McCarthy B-5 quadrangle, Alaska: U.S. Geol. Survey Misc. Geol. Inv. Map I-438.

, 1965b, Preliminary geologic map of the McCarthy C-6 quadrangle, Alaska: U.S. Geol. Survey Misc. Geol. Inv. Map I-444.

, 1969, Three newly named Jurassic formations in the McCarthy C-5 quadrangle, Alaska: U.S. Geol. Survey Bul1. 1274-A, p. 35-49, figs. 3-8. 
1970, Geologic map of the McCarthy B-4 quadrangle, Alaska: U.S. Geol. Survey Quad. Map GQ-943, scale $1: 63,360$ [In press].

MacKevett, E. M., Jr., 1970a, Geologic map of the McCarthy C-4 quadrangle, Alaska: U.S. Geol. Survey Geol. Quad Map GQ-844.

1970b, Geologic map of the McCarthy C-5 quadrangle, Alaska: U.S. Geol. Survey Geol. Quad. Map GQ-899.

,1971, Stratigraphy and general geology of the McCarthy C-5 quadrangle, Alaska: U.S. Geol. Survey Bull. 1323, 35p.

1972, Geologic map of the McCarthy C-6 quadrangle, Alaska: U.S. Geol. Survey Quad Map GQ-979.

Mackevett, E. M., Jr., and Placker, G., 1974, The Border Range fault in south-central Alaska: U.S. Geol. Survey, Journal of Research, vol. 2, no. 3, May-June 1974, p. 323-329.

MacKevett, E. M., Jr., and Smith, J. G., 1972, Geologic map of the McCarthy B-6 quadrangle, Alaska: U.S. Geol. Survey Quad Map GQ-1035.

Martin, G. C., 1906b, A reconnaissance of the Matanuska coal field, Alaska, in 1905: U.S. Geol. Survey Bull. 289, 36p. , 1916, Triassic rocks of Alaska: Geol. Soc. America Bull., v. 27, p. 685-718.

, 1926, The Mesozoic stratigraphy of Alaska: U.S. Geo. Survey Bull. 776,493 p.

Martin, G. C., and Katz, F. J., 1912, Geology and coal fields of the lower Matanuska Valley, Alaska: U.S. Geo. Survey Bull. 500, 98 p.

Martin, G. C., and Mertie, J. B., 1914, Mineral resources of the upper Matanuska and Nelchina valleys, in Brooks, A. H., and others, Mineral resources of Alaska, report on progress of investigations in 1913: U.S. Geol. Survey Bull. 592-H, p. 273-299.

Mendenhall, W. C., 1905, Geology of the central Copper River region, Alaska: U.S. Geol. Survey Prof. Paper 41, 133p.

Miller, D. J., and MacColl, R. S., 1964, Geologic map and sections of the northern part of the McCarthy A-4 quadrangle, Alaska: U.S. Geol. Survey Misc. Geol. Inv. Map I-410. 
Moffit, F. H., 1914, Geology of the Hanagita-Bremner region, Alaska: U.S. Geol. Survey Bull. 576, 56p.

, 1918, The upper Chitina Valley, Alaska: U.S. Geol. Survey Bull. 675, 82p.

- 1938, Geology of the Chitina Valley and adjacent area, Alaska: U.S. Geol. Survey Bull. 894, 137p.

Moffit, F. H., 1938a, Geology of the Chitina Valley and adjacent area, Alaska: U.S. Geol. Survey Bull. 894, p., 16 pls., 1 fig.

, 1938b, Geology of the Slana-Tok district, Alaska: U.S. Geol. Survey Bull. 904, 54 p., 4 pls., 4 figs.

, 1943, Geology of the Nutzotin Mountains, Alaska: U.S. Geol. Survey Bull. 933-B, p. 103-299, pls. 2-12, text- figs. 4-7.

, 1954, Geology of the eastern part of the Alaska Range and adjacent area: U.S. Geol. Survey Bull. 989-D, p. 65-218, pls. 6, 7, figs. 18-40.

Moffit, F. H. and Capps, S. R., 1911, Geology and mineral resources of the Nizina district, Alaska: U.S. Geol. Survey Bull. 448, 11p., 12 pls., 11 figs.

Moffit, F. H., and Knopf, Adolph, 1910, Mineral resources of the Nebesna-White River district, Alaska; with a section on the Quaternary, by S. R. Capps: U.S. Geol. Survey Bull. 417, 64p.

Nichols, D. R., and Yehle, L.A., 1961, Mud Volcanoes in the Copper River basin, Alaska: in Geology of the Artic, University of Toronto Press, p. 1063-1087.

, 1969, Engineering geologic map of the southeastern Copper River Basin, Alaska: U.S. Geol. Survey Misc. Geologic Investigations Map I-524.

Payne, T. G., 1955, Mesozoic and Cenozoic tectonic elements of Alaska: U.S. Geol. Survey Misc. Geol. Inv. Map I-84 scale $1: 5,000,000$.

Richter, D. H., 1971, Reconnaissance geologic map and section of the Nabesna B-4 quadrangle, Alaska: U.S. Geol. Survey Misc. Geol. Inv. Map I-656.

- 1973, Preliminary bedrock geologic map of the Nebesna quadrangle, Alaska: U.S. Geol. Survey open-file map, 1 sheet, scale 1:250,000. 
Richter, D. H., and Jones, D. I., 1973, Structure and stratigraphy of eastern Alaska Range, Alaska: Arctic Geology, Memoir, No. 19, Am. Assoc. of Petroleum Geologists.

Shaw, B. E., 1960, Preliminary evaluation of the oil and gas possibilities of the Copper River basin, Alaska: Amoco Production Co., Anchorage District Geol. Rept. No. XAB-5.

Smith, J. G., and Mackevett, E. M., Jr., 1970, The Skolai Group in the McCarthy $\mathrm{B}-4, \mathrm{C}-4$, and $\mathrm{C}-5$ quadrangles, Wrangell Mountains, Alaska: U.S. Geol. Survey Bull. 1274-Q, p. Q1-Q26.

Smith, T. E. and Turner, D. I., 1973, Geochronology of the McClaren Metamorphic Belt, South-Central Alaska; a progress report: Isochron/West, No. 7, August, 1973. 